\title{
THE ASSESSMENT OF ORGANIC AND NATURAL MAGNESIUM MINERAL FERTILIZERS GRANULATION AND THE DETERMINATION OF PRODUCED PELLET PROPERTIES
}

\begin{abstract}
Algirdas JASINSKAS, Institute of Agricultural Engineering and Safety, Faculty of Agricultural Engineering, Aleksandras Stulginskis University, Kaunas-Akademija, Studentu str. 15A, LT-53361, Kaunas r., Lithuania; algirdas.jasinskas@ asu.lt (coresponding author) Ramūnas MIELDAŽYYS, Institute of Agricultural Engineering and Safety, Faculty of Agricultural Engineering, Aleksandras Stulginskis University, Kaunas-Akademija, Studentu str. 15A, LT-53361, Kaunas r., Lithuania; ramunas.mieldazys@ asu.lt

Juozas PEKARSKAS, Institute of Environment and Ecology, Faculty of Forest Science and Ecology, Aleksandras Stulginskis University, Kaunas-Akademija, Studentu str. 11, LT-53361 Kaunas distr., Lithuania; juozas.pekarskas@ asu.lt

Sigitas ČEKANAUSKAS, Experimental Station, Aleksandras Stulginskis University, Rapsu str. 7, LT-53363 Noreikiskes, Kaunas distr., Lithuania; sigitas.cekanauskas@asu.lt

Antonin MACHALEK, Research Institute of Agricultural Engineering, Drnovská 507, Praha 6-Ruzyně 161 01, Praha 614, Chech Republic; antonin.machalek@vuzt.cz

Jiri SOUČEK, Research Institute of Agricultural Engineering, Drnovská 507, Praha 6-Ruzyně 161 01, Praha 614, Chech Republic; jiri.soucek@vuzt.cz

The research was carried out in Aleksandras Stulginskis University with a natural magnesium mineral fertilizer - magnesium silicate Serpentine rocks that were grounded and granulated with an impact granulation technology, organic cattle manure compost fertilizer, which was granulated using a device with a horizontal granulator matrix (the diameter of pellets is $6 \mathrm{~mm}$ ), and the mixture of Serpentine and manure pellets (mixture ratio 1:1, diameter of pellets is $6 \mathrm{~mm}$ ). There were investigated and estimated the biometric and physicalmechanical properties of produced fertilizer granules - pellet granulometric composition and biometric indicators, moisture content, density and pellet strength (resistance to impact forces). Research results showed that the pellet moisture content was sufficiently low, varied from $4.7 \%$ to $14.7 \%$, and the density of produced pellet was considerably high as it reached more than $1000 \mathrm{~kg} \mathrm{~m}^{-3} \mathrm{DM}$ (dry matter). Results on resistance to the deformation of the investigated mineral magnesium and organic fertilizers indicate that the most resistant granules are the ones that are made of the mixture of Serpentine and manure pellets as they decompose to $550.5 \mathrm{~N}$ force, whereas granules of manure pellets (without Serpentine) disintegrate to a $271.4 \mathrm{~N}$ force, which is about twice as small as the above mentioned one. Research results have shown that fertilizer granules made of organic manure and mixture with magnesium silicate Serpentine are of high quality, these granules are sufficiently resistant to compression on a static force as well as convenient for storage, transportation and mechanical spreading in the field.
\end{abstract}

Keywords: density, granules, magnesium fertilizers, manure, organic fertilizers, properties, serpentine, strength.

\section{INTRODUCTION}

Growing awareness and concern from the impact of stockbreeding wastes on the quality of life and the environment is capturing the attention of researchers who are focused on developing alternative methods of waste reduction and reuse. In Lithuania, agriculture generated approximately 3.8 million tons of manure in 2014 (Official, 2017). It has been calculated that 722 thousands of cattle theoretically produced about 7.81 million tons of solid fraction manure in 2016.

A promising approach for reducing volume, reducing offensive odours, and facilitating the storage of manure is drying and pelletizing. The reduced moisture content of the dried pelletized organic waste means that they are easier to store, transport, and apply to soil (John et al., 1996). These techniques may help to obtain a readily stored product that does not leach and does not have a bad odour, thus increasing its environmental acceptability and financial value. In addition, drying and pelletizing may reduce the significant pathogen load and antibiotic residue content of fresh litter (Sims and Wolf, 1994). Other manure uses, besides the land application, such as burning for fuel recovery or land filling, produce low-value alternatives. Solutions to transforming manure into valuable products are much more desirable than the current methods of manure disposal. The production of activated carbons can be an excellent reuse of these waste materials (Lima and Marshall, 2005).

The production of fertilizer from renewable organic waste sources (such as manure, animal waste, wood waste, etc.) using biological processes represents an important area of bio-fertilizer production. Farmyard manure is also a

Copyright (C) 2017 The Authors. Published by Aleksandras Stulginskis University. This is an open-access article distributed under the terms of the Creative Commons Attribution License (CC-BY 4.0), which permits unrestricted use, distribution, and reproduction in any medium, provided the original author and source are credited. 
valuable organic waste that has been traditionally used as a soil conditioner in agriculture. The organic component of solid waste contains sufficient amounts of nutrients that can be used as biological fertilizer (Ali et al., 2013).

In this article, manure refers to materials that have been composted and granulated. The densification process and pellet production is able to convert manure into a compressed form with advantages in transportation, handling, and storage (Bhattacharya et al., 1989). Biomass densification means the use of some form of mechanical pressure to reduce the volume of biomass material and the conversion of this material to a solid form (Erickson and Prior, 1990).

Hara studied the produced pellets by using an extruder from animal manure in order to investigate the effect of moisture content and dust levels on pellet strength (Hara, 2001). The obtained results showed that the strength pellets reduced with increasing moisture content and the percentage of the soil in manure. The most relevant moisture content level was proposed to be $45 \%$ for forming the pellets and below $20 \%$ for the storage of manure pellets.

According to scientific research, the crush strength is the most commonly used method to measure the hardness of fertilizer granules. It is defined as the minimum force required to crush individual particles. For fertilizers, it is a useful factor in predicting the expected handling and storage properties (Latifian et all, 2012).

After having assessed the suitability of manure compost for granulation, it has been established that this organic waste dried up to 10-12\% content humidity may be granulated using traditional feed granulators, and the process of granulation does not require any special equipment (Pocius et all, 2015). Lithuanian researchers have investigated that the experimental manure compost pellets with static stability limit $430 \mathrm{~N}$ were the most mechanically stable when subject to vertical compression, and the deformation level up to 1.2-1.3 $\mathrm{mm}$ (Pocius et all, 2016).

Composting, drying, and granulation are increasingly becoming a universal and popular option for environmentally sustainable means of recycling agricultural by-products. In Lithuania, commercial composting technology for conversion of large volume waste (cattle, pig, or hen manure) into economically viable and safe products has not been fully developed yet. Moreover, the densification of biomass materials into pellets could reduce costs and problems with handling, transportation, storage, and utilization of low bulk density biomass materials. There exists problems to produce good quality (i.e., high strength and durability) densified products from biomass whose densification characteristics are unknown, ways to make strong and durable densified products are needed.

Organic fertilizers are mainly used to enrich the soil with nitrogen, but many plants also require magnesium. A naturally extracted mineral serpentine can be used here. Serpentine $\left(\mathrm{Mg}_{6}\left[\mathrm{Si}_{4} \mathrm{O}_{10}\right][\mathrm{OH}]_{8}\right.$ or $\left.3 \mathrm{MgO}_{2} \mathrm{SiO}_{2} \cdot 2 \mathrm{H}_{2} \mathrm{O}\right)$ is volcanic and originates from rock solidification processes, consisting of such minerals as antigorite, lysart, calcite, and chlorite. Its chemical composition greatly depends on the place of extraction. Serpentine is rich in various elements that are also important for agricultural crops as nutrients. As an ornamental mineral, it is used to decorate the interior of buildings, in constructions, in fertilizer productions, as a feed additive, in water and gas purification and other fields (Harrison, Rajakaruna, 2001; Andreani et all., 2008; Deschamps et all., 2012; Lee, Soh, 2016). Serpentine is also used as a soil improver to improve soil properties and fertilize agricultural crops. The main reason for this is that serpentines are rich in magnesium, which is a very important element of plant nutrition - an integral part of chlorophyll (Skinner, 2005, Haynly et all., 2005; Senbayram et all., 2015).

The overall goal of this article is to investigate the properties of pressed organic and mineral magnesium fertilizers, to improve the strength and durability of the pressed products (granules), and to provide the conditions necessary to produce strong and durable pellets from manure, serpentine and their mix.

\section{MATERIALS AND METHODS}

The physical-mechanical characteristics of granulated cattle manure and Serpentine fertilizers were investigated: pellet moisture content; pellet biometric parameters and granulometric (fractional) composition; pellet measurements, mass, density, bulk density and the strength (resistance to compression) of granules. This research has been performed using the standard methods.

Pellet production. Three variants of pellets were produced: cattle manure compost, serpentine and their mixture (mixture ratio 1:1) in the laboratories of Aleksandras Stulginskis University (during the years 2016 and 2017). A press with horizontal array with $6 \mathrm{~mm}$ holes was used for the production of manure pellets' and mixture of manure-serpentine pellets'. For serpentine pellet production, the magnesium silicate serpentine rocks were grounded and granulated with impact granulation technology (Jasinskas et all., 2016).

After pressing and cooling the pellets, their granulometric composition, biometric parameters (dimensions, humidity, volume and density) and other properties were investigated.

Pellet granulometric composition was determined using a set of $200 \mathrm{~mm}$ diameter sieves with round holes of diameters $0.25 \mathrm{~mm}, 0.5 \mathrm{~mm}, 1.0 \mathrm{~mm}, 2.0 \mathrm{~mm}, 3.15 \mathrm{~mm}, 4.0 \mathrm{~mm}, 5.0 \mathrm{~mm}, 5.6 \mathrm{~mm}$, and $7.1 \mathrm{~mm}$. The mass remaining on the sieves was weighed, and sample fraction percentages were calculated. Each test was repeated 5 times.

Pellet moisture content was determined in a laboratory drying chamber oven according to the standard methodology presented in the paper (Šiaudinis et all., 2015).

Pellet parameters were determined by measuring their length and diameter (accuracy to $0.05 \mathrm{~mm}$ ). For all the experimental trials, 10 pellets were selected randomly. The pellet weight was assessed by KERN ABJ scales (accuracy to $0.001 \mathrm{~g}$ ). The weights were calculated for each type of pressed organic and mineral fertilizer using 10 granules. Pellet volume was calculated using the pellet size (diameter and length). The average mass meanings of the measured three sort granules were calculated. 
Pellet density. The pellet volume was calculated using the pellet size (diameter and length). After the determination of pellet mass and volume, their density was calculated (Jasinskas et all, 2016).

Pellet resistance to compression (strength). Pellet strength tests were carried out in laboratory of Institute of Agricultural Engineering and Safety Aleksandras Stulginskis University (ASU) by using a research equipment Instron 5960 and a command and parameter registration computer system Bluehill. Tests were carried out by placing pellets on a horizontal plane (table) and pressing by a vertical load (Jasinskas et all, 2016). The test results are recorded every 0.1 second until the pellet disintegrates when exposed to the force completely. The tests were repeated 5 times for the pellets of the tested 3 samples. Measurement error is $0.02 \%$. When all the tests were performed, the research data was processed by statistical-mathematical methods.

\section{RESULTS AND DISCUSSION}

Determination of pellets properties. Granulation technology and pellet properties depend on the equipment that was used, raw material, mass fractional composition, and moisture content.

Granulometric composition and other properties of organic pellet depend on the main parameters of the produced pellet. It was determined that the average mass of the produced $6.0 \mathrm{~mm}$ diameter organic fertilizer pellets varied from $0.30 \mathrm{~g}$ to $0.56 \mathrm{~g}$ and average length of the pellet was $9.9 \pm 1.0 \mathrm{~mm}$. The largest amount of fraction was received on the sieves with $5.6 \mathrm{~mm}$ holes - fraction varied from $61.2 \%$ to $82.0 \%$ (in organic manure compost pallets). Very small amount was received on the sieves with small holes (diameter to $2 \mathrm{~mm}$ ), all this fraction varied from $1.1 \%$ to $2.4 \%$.

Moisture content has a significant influence on pellet quality and properties. Dry pellets quickly absorb ambient moisture, may swell, disintegrate and turn into its original state as before granulation. Dry raw materials with a moisture content of 15-20\% should be used for pellet production, so it is necessary to estimate the granulated pellet moisture content.

Research has shown that moisture contents of the investigated three types of pellets vary from each other, even when the storing conditions of the pellets were the same. Determined moisture content and density of pellets is presented in Table 1.

Table 1. Moisture content of organic and mineral fertilizer pellets

\begin{tabular}{|c|c|c|}
\hline Raw material of pellets & The sample average moisture content, $\mathrm{w}_{\mathrm{i}} \pm \Delta \mathrm{y}, \mathrm{c} \%$ & Pellet density, $\mathrm{kg} \mathrm{m}^{-3}$ \\
\hline Cattle manure compost & $14.66 \pm 2.06$ & $\begin{array}{c}1217.47 \pm 64.37 \\
1038.98 \pm 54.93 \mathrm{DM}\end{array}$ \\
\hline Magnesium silicate serpentine & $4.76 \pm 0.36$ & $\begin{array}{c}1319.2 \pm 340.2 \\
1255.9 \pm 324.0 \mathrm{DM}\end{array}$ \\
\hline $\begin{array}{l}\text { Manure and serpentine mixture } \\
\text { (ratio 1:1) }\end{array}$ & $10.19 \pm 1.24$ & $\begin{array}{c}1280.3 \pm 120.8 \\
1149.8 \pm 108.5 \mathrm{DM}\end{array}$ \\
\hline
\end{tabular}

According to the determined data, it can be stated that the maximum moisture content is in organic manure compost pellets $-14.7 \pm 2.06 \%$, and the lowest is in magnesium silicate serpentine pellets $-4.76 \pm 0.36 \%$.

From the data of Table 1 it can be seen that the biggest density is of mineral fertilizer, magnesium silicate serpentine pellets $-1255.9 \pm 324.0 \mathrm{~kg} \mathrm{~m}^{-3} \mathrm{DM}$ (dry material), and the lowest density is of cattle manure compost pellets $1038.98 \pm 54.93 \mathrm{~kg} \mathrm{~m}^{-3} \mathrm{DM}$. Finally it could be stated, that all sorts of investigated fertilizer pellets had sufficient high density, it reached more than $1000 \mathrm{~kg} \mathrm{~m}^{-3} \mathrm{DM}$

Determination of pellet resistance to degradation. Compressive resistance (crushing resistance or hardness) is the maximum crushing load a pellet can withstand before cracking or breaking. We named that dimension compression strength test. Having performed research in compression strength of three types of granules of mineral magnesium and organic fertilizers, we received the results that are presented in Fig.1. During the tests, the beginning of deformation of the force under which a granule is disintegrated was determined in horizontal direction. Results on resistance to the deformation of the investigated mineral magnesium and organic fertilizers indicate that the highest resistance is the granules made of Serpentine and manure pellets mixture, they decompose to $550.5 \mathrm{~N}$ force, granules of manure pellets (without serpentine) disintegrate to about two times smaller force $-271.4 \mathrm{~N}$.

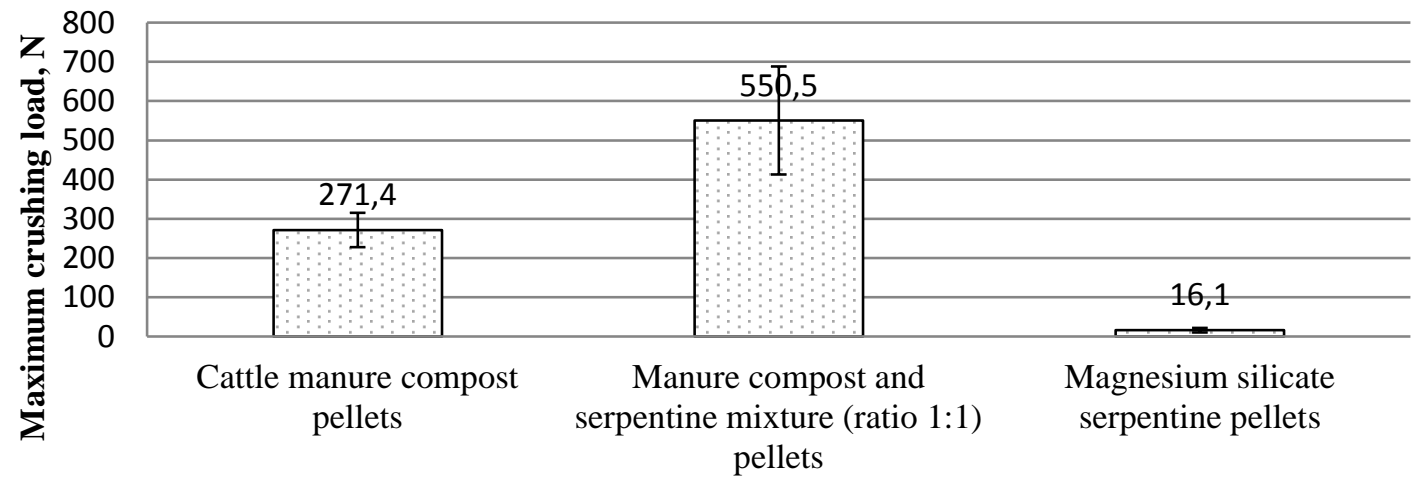

Figure 1. Organic fertilizers and mineral magnesium pellets strength (maximum crushing load) test results 
Cattle manure compost pellets without serpentine strength test of each 5 samples are shown in Fig. 2. When analysing the deformation curve of 5 samples, we see that the maximum crushing load achieved more than $300 \mathrm{~N}$ and deformation were from $0.1 \mathrm{~mm}$ till $0.5 \mathrm{~mm}$. Granules do not disintegrate immediately, that shows elasticity properties.

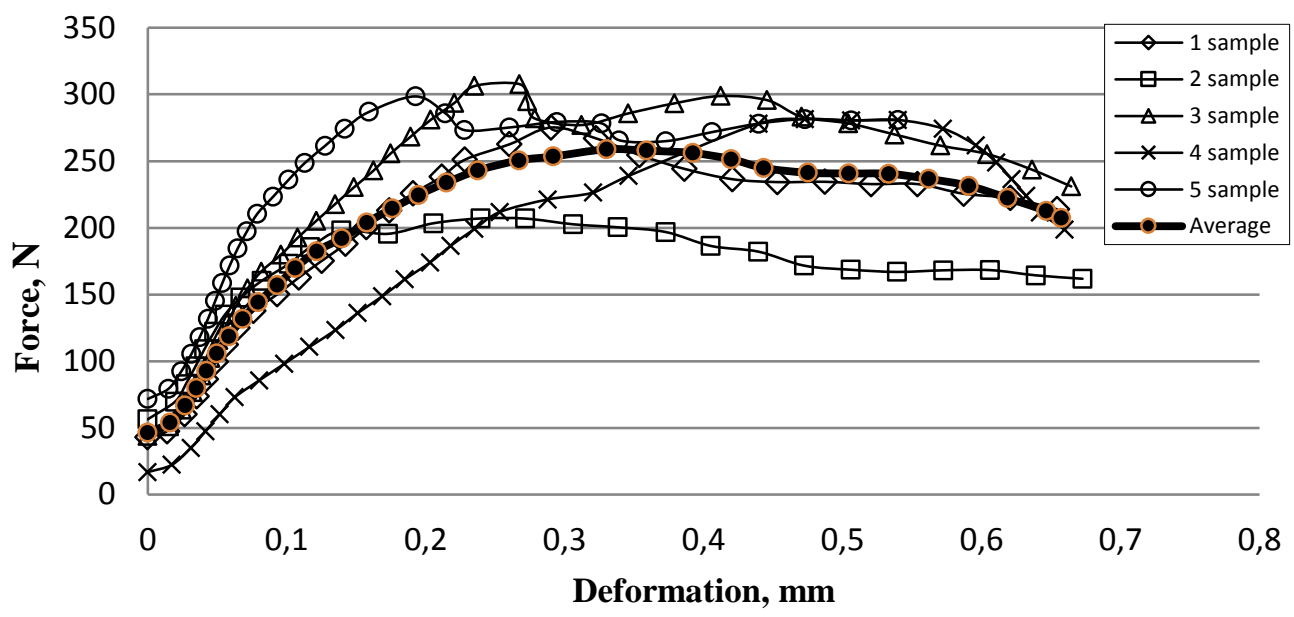

Figure 2. The strength test of cattle manure compost pellets

The mixture of serpentine and manure compost pellets (mixture ratio 1:1) strength test of each 5 samples is shown in Fig. 3. When analysing the deformation curve of 5 samples, we see that the maximum crushing load achieved more than $700 \mathrm{~N}$ and deformation was also from $0.1 \mathrm{~mm}$ till $0.4 \mathrm{~mm}$. Granules disintegrated more quickly, curves were more broken, which possibly happened because of the impact of the added serpentine.

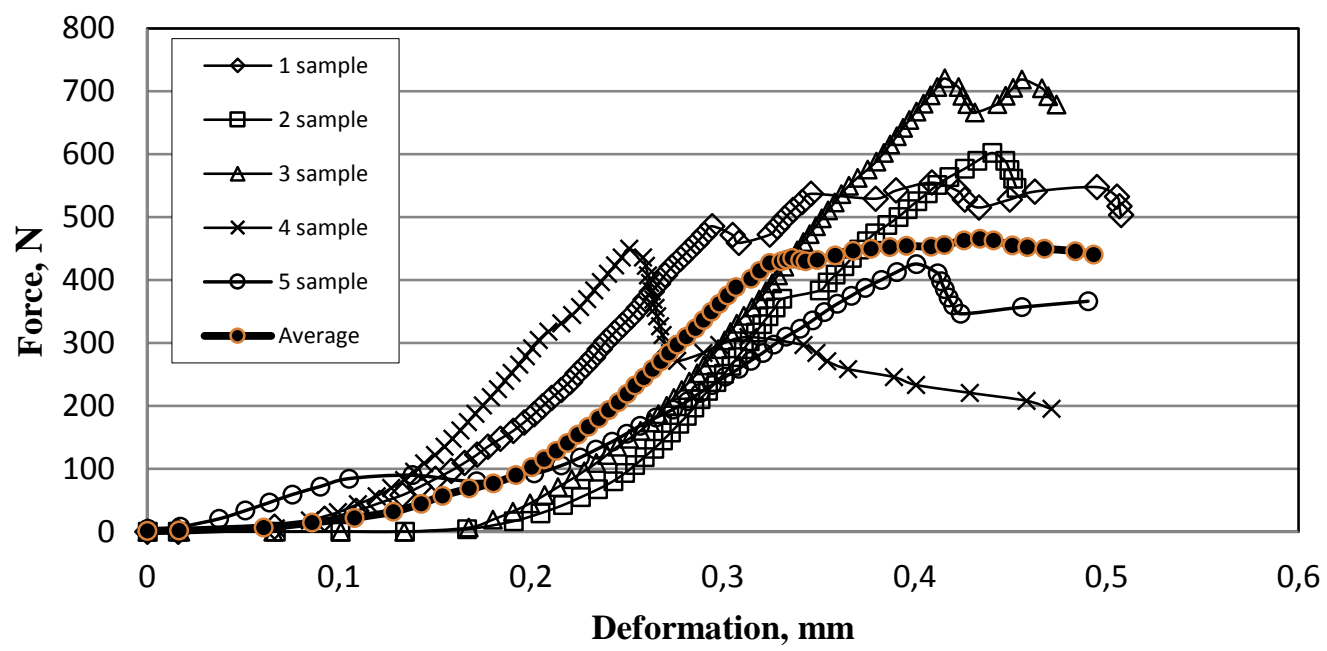

Figure 3. The strength test of cattle manure compost pellets with serpentine (mixture ratio 1:1)

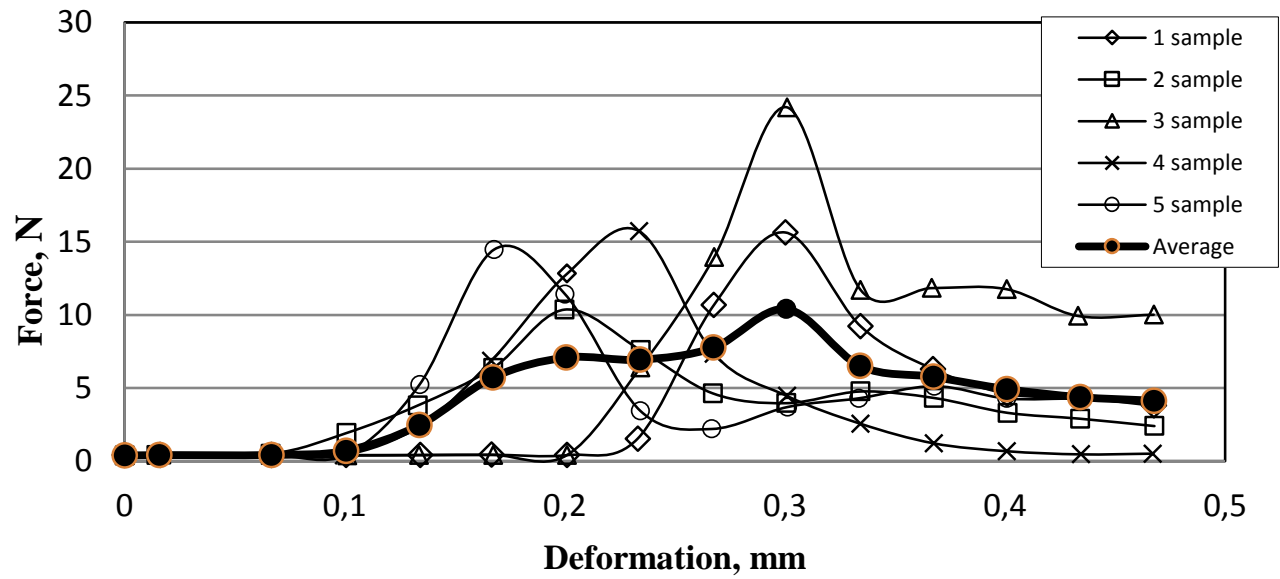

Figure 4 . The strength test of pure serpentine 
Investigated the pure serpentine pellet strength test is presented in Fig. 4. From the chart presented in this figure it can be seen that a granule started to deform under the force of $1.0 \mathrm{~N}$, and under the average force of $16 \mathrm{~N}$ it deformed and disintegrated. Having evaluated the force and its change and low moisture content of the granules $(4.8-14.7 \%)$, it can be stated that these granules are not sufficiently resistant to static force and disintegrate too quickly.

The research results show that fertilizer granules made of organic manure and mixture with magnesium silicate serpentine are of high quality, these granules are sufficiently resistant to compression on a static force, convenient for storage, transportation, and mechanical spreading in the field.

\section{CONCLUSIONS}

1. There were produced and investigated three variants of fertilizer pellets: cattle manure compost, serpentine and their mixture (ratio 1:1). The determined pellet moisture content varied from $4.76 \pm 0.36 \%$ (serpentine pellets) to $14.7 \pm 2.06 \%$ (manure compost pellets).

2. The investigated fertilizer pellets had sufficient high density, it reached more than $1000 \mathrm{~kg} \mathrm{~m}^{-3} \mathrm{DM}$. The highest density was of serpentine pellets $-1255.9 \pm 324.0 \mathrm{~kg} \mathrm{~m}^{-3} \mathrm{DM}$ (dry material), and the lowest density was of manure pellets $-1038.98 \pm 54.93 \mathrm{~kg} \mathrm{~m}^{-3} \mathrm{DM}$.

3. The fertilizer granules produced of organic manure and mixture with magnesium silicate serpentine are sufficiently resistant to compression (maximum crushing load achieved $271.4 \mathrm{~N}$ and $550.5 \mathrm{~N}$ ) and they are convenient for storage, transportation and mechanical spreading in the field. However, granules produced of pure Serpentine are not sufficiently resistant to static force and disintegrate too quickly.

\section{REFERENCES}

1. Official Statistic Portal 2017. https://osp.stat.gov.lt/EN/statistiniu-rodikliu-analize?hash=af9953af-3ff9-4d90-8c92$\underline{6335 \mathrm{ddc} 0 \mathrm{c} 012 \# /}$. Accessed on 7.9.2017.

2. John, N.M., Adeoye, G.O., Sridhar, M.K.C., 1996. Compost pelletization eases end use in Nigeria. Biocycle, Vol. 37, No. 6, pp. 55-56.

3. Sims, J.T., Wolf, D.C., 1994. Poultry waste management: agricultural and environmental issues. Adv. Agron. 52, 1-83 p.

4. Lima I M, Marshall W E 2005. Granular activated carbons from broiler manure: physical, chemical and adsorptive properties. Bioresource Technology, Vol. 96, pp. 699-706. https://doi.org/10.1016/j.biortech.2004.06.021

5. Ali, M., Khan, Z.M., Raja, I.A. 2013.Treatment of organic solid waste for reuse: a step towards zero waste. Science Vision, Vol. 19, Iss. 1,2, pp. 63-66.

6. Bhattacharya, S.C., Sett, S., Shrestha, R.M. 1989. State of the Art of Biomass Densification, Energy Source. Division of Energy Technology, Vol. 11, Iss. 3, pp. 161-186.

7. Erickson, S. \& Prior, M. 1990. The Briquetting of Agricultural Wastes for Fuel. FAO Environment and energy paper 11. FAO, Via delle Terme di Caracalla, 00100 Rome, Italy.

8. Hara, M. 2001. Fertilizer pellets made from composted livestock manure. Food \& Fertilizer Technology Center, Taiwan. http://www.fftc.agnet.org/library.php?func=view\&id=20110801154610 . Accessed on: 09012016.

9. Latifian, M., Liu, J., Mattiasson B. 2012. Struvite-based fertilizer and its physical and chemical properties. Environmental Technology, Vol. 33, pp. 2691-2697. https://doi.org/10.1080/09593330.2012.676073

10. Pocius, A., Jotautienė, E., Domeika, R., Jasinskas, A., Kučinskas, V., Palšauskas, M. 2015. Investigation of granulation process influence to granulated organic compost fertilizer properties. Engineering for Rural Development: 14th International Scientific Conference: Proceedings, May 20-22, 2015. Vol. 14. pp. 829-834.

11. Pocius, A., Jotautienè, E., Pekarskas, J., Palšauskas, M. 2016. Investigation of physical-mechanical properties of experimental organic granular fertilizers. Engineering for Rural Development: 15th International Scientific Conference: Proceedings, May 2527, 2016. Vol. 15, pp. 1115-1120.

12. Harrison, S., Rajakaruna, N. 2001. Serpentine: the evolution and ecology of a model system, University of California Press.

13. Andreani, M., Grauby, O., Muňzon, M. 2008. Occurrence, composition and growth of polyhedral serpentine. European Journal of Mineralogy, Vol. 20, pp. 159-171. https://doi.org/10.1127/0935-1221/2008/0020-1801

14. Deschamps, F., Godard, M., Guillot, S., Chauvel, C., Andreani M, Hattori, K., Wunder, B., France L. 2012. Behavior of fluidmobile elements in serpentines from abyssal to subduction environments: Examples from Cuba and Dominican Republic. Chemical Geology, Vol. 31, Iss. 2, pp. 93-117.https://doi.org/10.1016/j.chemgeo.2012.04.009

15. Lee, J.K., Soh, J.S. 2016. Performance of Magnesia Cement Using MgCO3 and Serpentine. Journal of the Korean Ceramic Society, Vol. 53, Iss. 1, pp. 161-121. https://doi.org/10.4191/kcers.2016.53.1.116

16. Skinner, H. C. W. 2005. The Web of Magnesium. International Geology Review 47:11, pp. 1111-1119. https://doi.org/10.2747/0020-6814.47.11.1111

17. Hanly, J. A., Loganathan, P., Currie, L. D. 2005. Effect of serpentine rock and its acidulated products as magnesium fertilisers for pastule, compared with magnesium oxide and Epsom salts, on a Pumice Soil. 1. Dry matter yield and magnesium uptake. New Zealand Journal of Agricultural Research, Vol. 48, Iss. 4, pp. 451-460. https://doi.org/10.1080/00288233.2005.9513679

18. Senbayram, M., Gransee, A., Wahle, V., Thiel, H. 2015. Role of magnesium fertilisers in agriculture: plant-soil continuum. Crop \& Pasture Science, Vol. 66, pp. 1219-1229. https://doi.org/10.1071/CP15104 
19. Jasinskas, A., Pekarskas, J., Kučinskas, V., Aboltins, A. 2016. Investigation of natural magnesium mineral fertilizer granulation and determination of granule qualitative indicators. Engineering for Rural Development: 15th International Scientific Conference : Proceedings. Jelgava, 2016 May 25-27, vol. 15, pp. 647-652.

20. Šiaudinis, G., Jasinskas, A., Šarauskis, E., Steponavičius, D., Karčiauskienė, D., Liaudanskienė, I. 2015. The assessment of Virginia mallow (Sida hermaphrodita Rusby) and cup plant (Silphium perfoliatum L.) productivity, physicoemechanical properties and energy expenses. Energy, Vol. 93, Iss. 1, pp. 606-612. https://doi.org/10.1016/j.energy.2015.09.065 